\title{
PENYUSUNAN ANGGARAN PERSPEKTIF FIQHI ANGGARAN HUKUM EKONOMI SYARIAH
}

\author{
Abdul Kadir Arno \\ Fakultas Syariah Institut Agama Islam Negeri (IAIN) Palopo \\ Email : abdulkadir.arno@iainpalopo.ac.id
}

\begin{abstract}
In managing the budget, honesty (shidq) is a liability, which can't be executed unless the application of the principle of budget transparency. Therefore, based on the rules then, do the transparency of the budget is mandatory. In the view of Islam, avoiding the transparency of the budget is disobedience. The application of the basic values of Islamic law in the preparation of the budget becomes extremely important in anticipating the leak. In this context the existence of fiqh budget is very urgent, because it is not just for the sake of personal interest but also the public. Therefore the parties involved in the preparation of the budget should be linked by law, so that the consequences of which can be accounted for before the courts in case of fraud.
\end{abstract}

Keywords: Budget, Economic Law Sharia

\begin{abstract}
Abstrak
Dalam mengelola anggaran, kejujuran (shidq) adalah kewajiban, yang tidak dapat dieksekusi kecuali penerapan prinsip transparansi anggaran. Karena itu, berdasarkan aturan maka, lakukan transparansi anggaran itu wajib. Dalam pandangan Islam, menghindari transparansi anggaran adalah ketidaktaatan. Penerapan nilai-nilai dasar hukum Islam dalam penyusunan anggaran menjadi sangat penting dalam mengantisipasi kebocoran. Dalam konteks ini keberadaan anggaran fiqh sangat mendesak, karena tidak hanya untuk kepentingan pribadi tetapi juga masyarakat. Karena itu para pihak yang terlibat dalam penyusunan anggaran harus dihubungkan oleh hukum, sehingga konsekuensinya dapat dipertanggungjawabkan di pengadilan jika terjadi kecurangan.
\end{abstract}

\section{Kata Kunci : Anggaran, Hukum Ekonomi Syariah}

\section{PENDAHULUAN}

Pada era sekarang ini, Lembaga atau sebuah organisasi baik bersifat profit (sektor swasta) maupun nonprofit (Pemerintah) adalah yang mampu melakukan efisiensi, peningkatan mutu, dan mampu mem-pertahankan kelangsungan hidup organisasi dan terus berkembang. Kondisi tersebut menuntut para pemangku kebijakan untuk meningkatkan kinerja yang tidak lepas dari kemampuan dalam perencanaan, peng-koordinasian, dan pengendalian berbagai aktivitas dan sumber daya yang dimiliki. Dalam menjalankan sebuah organisasi, ada berbagai 
fungsi yang harus dilakukan oleh seorang manajer. Fungsi-fungsi tersebut adalah perencanaan (planning) pengendalian (controlling), dan pengambilan keputusan (decision making). ${ }^{1}$

Perencanaan sebagai titik tolak men-jalankan kegiatan organisasi, memegang peranan yang sangat penting. Berdasarkan jangka waktunya, perencanaan dapat dibeda-kan menjadi perencanaan jangka panjang dan jangka pendek. Perencanaan jangka panjang organisasi tertuang dalam visi, misi, strategi dan program, sedangkan peren-canaan jangka pendek akan diturunkan berdasar perencanaan jangka panjang. Perencanaan jangka pendek yang disajikan dalam bentuk angka-angka disebut dengan anggaran.

Organisasi memerlukan anggaran sebagai salah satu komponen penting agar tetap survive dalam menjalankan suatu aktivitas untuk menerjemahkan seluruh strategi menjadi rencana dan tujuan jangka pendek dan jangka panjang. ${ }^{2}$ Anggaran merupakan gambaran kuantitatif dari tujuan-tujuan manajemen dan menjadi alat untuk menentukan kemajuan dalam mencapai tujuan tersebut.

Pada umumnya suatu organisasi atau lembaga menggunakan anggaran sebagai salah satu langkah awal dalam melaksana-kan aktivitas. Anggaran adalah alat peren-canaan dan pengendalian yang sangat pen-ting dalam suatu kelembagaan, sehingga proses penyusunan anggaran merupakan aspek penting dalam pencapaian keberhasil-an suatu organisasi. Anggaran tidak saja sebagai alat perencanaan keuangan dan pengendalian, tetapi juga sebagai alat koordinasi, komunikasi, evaluasi kinerja dan motivasi ${ }^{3}$ serta alat untuk mendelegasikan wewenang atasan kepada bawahan. Lebih lanjut menurut Hanson pengendalian dalam anggaran mencakup pengarahan dan penga-turan orang-orang dalam organisasi. Proses penyusunan anggaran merupakan proses penetapan peran, dimana pihak-pihak yang berkaitan diberi peran untuk melaksanakan kegiatan pencapaian sasaran yang ditetapkan dalam anggaran. $^{4}$

Proses penyusunan anggaran meru-pakan kegiatan yang penting dan melibatkan berbagai pihak baik manajer tingkat atas maupun manajer tingkat bawah. Para mana-jer akan memainkan peranan dalam mem-persiapkan dan mengevaluasi berbagai alternative dari tujuan anggaran, ketika anggaran digunakan sebagai tolok ukur kinerja manajer. ${ }^{5}$ Penyusunan anggaran merupakan proses pembuatan rencana kerja dalam rangka waktu satu tahun, yang dinyatakan dalam satuan moneter dan satuan kuantitatif orang lain. Pada dasarnya, penyusunan anggaran dapat dibagi menjadi dua yaitu penganggaran partisipatif (bottom-up) yang disusun dengan memberikan kesem-patan bagi manajer level bawah untuk ber-partisipasi dalam pembentukan anggaran; dan penganggaran top-down, yang disusun dengan tidak melibatkan partisipasi bawahan secara signifikan. ${ }^{6}$

${ }^{1}$ Endang Raino Wirjono dan Agus Budi Raharjono,"Pengaruh Karakteristik Personalitas Manajer Terhadap Hubungan Antara Partisipasi Dalam Penyusunan Anggaran Dengan Kinerja Manajerial", Kinerja, Vol. 11 No. 1, thn 2007) h., 50-63..

54

${ }^{2}$ Hansen Don R, Momen, M, , Akuntansi Mangemen, Jakarta, Penerbit Salemba Empat: 2006), h.

${ }^{3}$ Ibid.

${ }^{4}$ Ibid

${ }^{5}$ George R. Terry \& Leslie W. Rue. Dasar-Dasar Manajemen, Jakarta: Bumi Aksara. 2009 dalam Endang dan Agus, op.cit.

${ }^{6}$ Abdul Halim, Akuntansi Sektor Publik akuntansi Keuangan Daerah (Jakarta : Salemba empat, 2002 
Dalam penyusunan anggaran pada sebuah organiasiasi atau kelembagaan di-butuhkan sebuah perencanaan yang matang. Anggaran yang disusun haruslah sesuai dengan kebutuhankebutuhan setiap orga-nisasi atau kelembagaan tersebut untuk mencapai visi dan misi yang tertuang dalam Renstra organiasiasi atau kelembagaan ter-sebut. Renstra inilah yang nantinya menjadi tolak ukur dalam pencapaian kinerja suatu organisasi. Oleh karenanya, setiap anggaran yang disusun juga harus memiliki tolak ukur atas kinerja yang nantinya akan dicapai.

Namun diakui atau tidak kebocoran anggaran, realita yang ada terjadi dalam semua organisas atau kelembagaan berkaitan dengannya. Apabila ada sebagian pengamat, pakar, ilmuwan atau anggota masyarakat yang menyangkal hal tersebut, barangkali hanya berusaha berprasangka baik, selebih-nya mungkin menutup mata dan telinga terhadap kenyataan yang ada. Salah satu modus dalam perencanaan anggaran yang dilakukan adalah dengan melakukan peng-gelembungan anggaran atau mark-up budget yaitu menaikkan nilai anggaran dari nilai yang sebenarnya. ${ }^{7}$ Biasanya hal tersebut terjadi dalam proyek dengan cara menggelembungkan besarnya dana proyek seper-ti memasukkan pos-pos pembelian yang sifatnya fiktif (split budget) yang dilakukan dengan membuat item atau mata anggaran yang sebenarnya tidak pernah direalisasikan untuk tujuan tertentu, namun dialokasikan untuk kepentingan lainnya. Dapat diberikan contoh misalnya dalam anggaran dimasuk-kan pembelian printer, tetapi pada praktik-nya tidak ada printer yang dibeli, atau kalau dibeli harganya lebih murah.

Dalam ilustrasi di atas, terdapat ke-mungkinan ada kebocoran anggaran sehing-ga tidak semua dana dialokasikan untuk proyek tersebut. Bahkan telah menjadi rahasia umum, kontraktor harus menyisih-kan dana sekian persen untuk oknum-oknum di birokrasi agar dimenangkan dalam tender dan mendapatkan proyek. Dalam berbagai kasus, proses penentuan kebijakan termasuk dalam penganggaran hanya formalitas belaka, sebab dibalik prosedur formal tersebut sebenarnya sudah tersisipkan titipan-titipan dari para kolega dan kroni-kroni yang memanfaatkan kedekatannya dengan penguasa untuk memperkaya diri, keluarga, dan atau kelompoknya. ${ }^{8}$

Fenomena kebocoran anggaran ter-sebut sudah menjadi realitas yang terjadi di Republik ini, kebocoran tersebut akibat praktik KKN yang berkaitan dengan kegia-tan pengadaan barang dan jasa. ${ }^{9}$ Realitas tersebut masih tetap berlanjut hingga kini, kegiatan pengadaan barang dan jasa peme-rintah, masih berpotensi menjadi ladang subur korupsi. Dalam konteks perkembangan ekonomi Islam di Indonesia, bagai-mana hukum ekonomi Islam merespon fenomena tersebut. Menurut Mulyadi pengertian ang-garan adalah suatu rencana kerja yang dinyatakan secara kuantitif yang mencakup jangka waktu satu tahun. ${ }^{10}$ Menurut Hanson dalam Riyadi anggaran adalah: Suatu per-nyataan formal yang dibuat oleh manaje-men tentang rencana yang akan dilakukan pada masa yang akan datang dalam suatu periode tertentu, dimana rencana tersebut akan digunakan sebagai pedoman dalam pelaksanaan kegiatan selama periode tersebut. ${ }^{11}$

\footnotetext{
${ }^{7}$ Indonesia Coruption Watch, Korupsi Anggaran, http://www.antikorupsi.org/

${ }^{8}$ Iskandar Siregar, "Menuju Era Transparansi Anggaran", http://www.kabar Indonesia.com akses 23 Februari 2015

${ }^{9}$ Anonim,"Penggelembungan Anggaran Modus laten Korupsi" http://www.anggaran. depkeu.go.id. akses akses 23 Februari 2015

${ }^{10}$ Mulyadi, Akuntansi Biaya (Yogyakarta: BP-STIE YKPN, 1993), h. 488

${ }^{11}$ Riyadi, S.. Motivasi dan Pelimpahan Wewenang Sebagai Variabel Moderating dalam Hubungan Antara Partisipasi Penyusunan Anggaran dan Kinerja Manajerial. Jurnal Riset Akuntansi Indonesia. Vol 3, No. 2, Tahun 2000, h. 137.
} 
Alat penting untuk perencanaan dan pengendalian dalam suatu organisasi adalah anggaran. Anggaran juga merupakan ren-cana keuangan perusahaan yang digunakan sebagai pedoman untuk menilai kinerja ${ }^{12}$ alat koordinasi dan komunikasi antara pim-pinan dengan bawahan dalam organisasi, ${ }^{13}$ dan alat untuk mendelegasikan wewenang pimpinan kepada bawahan. Dari pengertian-pengertian di atas, dapat diperoleh makna bahwa anggaran berisi rencana kerja, ren-cana keuangan yang berhubungan dengan aktivitas perusahaan/institusi dalam jangka waktu tertentu.

Penyusunan anggaran mempunyai empat tujuan utama, yaitu: 1) untuk menye-suaikan rencana strategis; 2) untuk mem-bantu mengkoordinasikan aktivitas dari beberapa bagian organisasi; 3) untuk menu-gaskan tanggung jawab kepada manajer, untuk mengotorisasi jumlah yang berwenang untuk mereka gunakan, dan untuk meng-informasikan kepada mereka mengenai kinerja yang diharapkan dari mereka, dan; 4) untuk memperoleh komitmen yang meru-pakan dasar untuk mengevaluasi kinerja aktual manajer. Anggaran sebaiknya men-jadi cetak biru keuangan mengenai bagai-mana perusahaan/istitusi diharapkan untuk beroperasi. Anggaran telah menjadi alat mana-jemen yang diterima untuk merencana-kan dan mengendalikan aktivitas organisasi. Anggaran diterapkan dengan berbagai ting katan kerumitan dan keberhasilan oleh banyak organisasi bisnis dan nirlaba.

\section{KARAKTERISTIK PROSES PENYUSUNAN ANGGARAN}

Anggaran merupakan alat penting untuk perencanaan dan pengendalian jangka pendek yang efektif dalam organisasi. Suatu anggaran operasi biasanya meliputi waktu satu tahun dan menyatakan pendapatan dan beban yang direncanakan untuk satu tahun itu. Menurut Anthony dan Govindarajan, anggaran mempunyai karakteristik: 1) Ang-garan mengestimasikan potensi laba dari unit bisnis tersebut, 2) Merupakan komitmen manajemen, yang berarti manajer menye-tujui serta telah ditinjau oleh pejabat yang lebih tinggi wewenangnya dari pembuat anggaran untuk menerima tanggung jawab atas pencapaian tujuan-tujuan anggaran. ${ }^{14}$

Suatu anggaran harus dapat me-motivasi manajer dan karyawan untuk me-menuhi sasaran yang telah ditetapkan dalam anggaran sehingga meningkatkan efektifitas anggaran. Oleh karena itu ang-garan harus memperhatikan aspek perilaku manusia. Kenis mengembangkan lima karakteristik anggaran yang memperhatikan perilaku manusia. Karakteristik tersebut adalah:

1. Budgetary Participation (partisipasi anggaran). Mengacu pada sejauh mana manajer berpartisipasi dalam menyu-sun anggaran dan mempengaruhi sasaran anggaran untuk pencapaian prestasinya.

2. Budgetary Goal Clarity (kejelasan sa-saran anggaran). Mengacu pada sejauh mana sasaran anggaran dinyatakan secara jelas dan spesifik, juga dimengerti oleh para manajer yang bertugas mencapai sasaran anggaran.

3. Budgetary Feedback (umpan balik anggaran). Umpan balik tentang tingkat pencapaian sasaran anggaran adalah variable motivasi yang sangat penting.

${ }^{12}$ Schiff, M. and A.W. Lewin.. The Impact of People on Budgets.The Accounting Review. Vol. 45, 1970. pp. $259-268$

${ }^{13}$ Kenis, I.. Effects of Budgetary Goal Characteristic on Managerial Attitude and Performance, Accounting Review Oct 1979. pp 707-721

${ }^{14}$ Anthony dan Govindarajan. Manage-ment Control System, Penerbit Salemba Empat, Jakarta 2005), h. 27 
4. Budgetary Evaluation (evaluasi ang-garan). Evaluasi anggaran mengacu pada selisih anggaran yang ditelusuri ke manajer pusat pertanggung jawaban dan dipakai untuk mengevaluasi kinerja.

5. Budget Goal Difficulty (tingkat kesu-litan sasaran anggaran). Sasaran ang-garan yang sangat mudah dicapai tidak mencerminkan tantangan dan memiliki pengaruh motivasional yang rendah. Di lain sisi, sasaran yang sangat sulit untuk dicapai mengakibatkan perasaan gagal, frustasi, penolakan dan aspirasi yang rendah.

Penyusunan anggaran dalam suatu organisasi biasanya dilakukan oleh depar-temen anggaran dan komite anggaran. Departemen anggaran menangani arus informasi dari sistem pengendalian ang-garan. Komite anggaran yang terdiri dari anggota-anggota manajemen senior, me-ninjau dan menyetujui atau menyesuaikan masing-masing anggaran. Komite anggaran juga harus menyetujui revisi anggaran besar yang dibuat selama satu tahun. Menurut Siegel dan Marcony dalam Asnawi, ada tiga tahapan utama dalam proses penyusunan anggaran, yaitu:

1. Penetapan Tujuan

Perencanaan dimulai dengan men-terjemahkan tujuan organisasi yang luas ke dalam tujuan-tujuan aktivitas yang khusus.

2. Implementasi

Pada tahap implementasi, rencana formal tersebut digunakan untuk meng komunikasikan tujuan dan strategi orga-nisasi, serta untuk memotivasi orang secara positif dalam organisasi.

3. Pengendalian dan Evaluasi Kinerja.

Setelah anggaran diimplementasi-kan, maka anggaran tersebut berfungsi sebagai elemen kunci dalam sistem pengendalian. Anggaran menjadi tolak ukur terhadap manajemen kinerja actual dan berfungsi sebagai suatu dasar untuk melakukan manajemen berdasarkan pengecualian.

\section{PRINSIP-PRINSIP HUKUM EKONOMI ISLAM TERHADAP PERENCANAAN ANGGARAN}

Anggaran didefinisikan oleh Glenn A Welsch sebagai "Profit planning and contro may be broadly as defined as sistematic and formalized approach for accomplishing the planning, coordinating and control respon-sibility ofmanagement" 15 Dengan demikian, anggaran harus dikaitkan dengan fungsi-fungsi dasar manajemen yang meliputi fungsi perencanaan, koordinasi dan penga-wasan sebagai bentuk pertanggungjawaban manajemen.

Interpretasi dari hal tersebut adalah, (1) Anggaran harus bersifat formal yang disusun dengan sengaja serta bersungguh-sungguh dalam bentuk tertulis dan teliti, (2) Anggaran harus sistematis yang disusun dengan berurutan dan berdasarkan logika, (3) Setiap manajer dihadapkan pada suatu tanggungjawab untuk mengambil keputusan, sehingga anggaran merupakan hasil peng-ambilan keputusan yang berdasarkan asumsi tertentu, (4) Keputusan yang diambil oleh manajer tersebut, merupakan pelaksanaan fungsi manajer dari segi perencanaan, pengorganisasian, mengarahkan dan peng-awasan.

Melalui anggaran, organisasi meng-komunikasikan rencana-rencana manajemen ke semua anggota organisasi, mengkoor-dinasikan aktivitas dari berbagai bagian organisasi,

15 Glenn A.Welsch, Budgeting Profit Planning and Control, fourth edition, (New Delhi: prentice hall of India Private Limited, 1981), h.3 
menugaskan tanggungjawab kepada manajer, juga memperoleh komit-men dari manajer yang merupakan dasar untuk mengevaluasi kinerja dari manajer.

Meskipun penyusunan anggaran me-rupakan tanggung jawab pimpinan tertinggi organisasi, namun dapat didelegasikan kepada bagian yang terkait seperti bagian administrasi yang menyimpan seluruh data aktivitas organisasi. Pendelegasian tersebut dapat juga diberikan kepada panitia ang-garan yang terdiri dari pimpinan dan wakil masing-masing bagian terkait.

Fungsi anggaran pada suatu orga-nisasi merupakan alat untuk membantu pimpinan dalam pelaksanaan fungsi peren-canaan, koordinasi, pengawasan dan juga sebagai pedoman kerja dalam menjalan-kan program kerja untuk tujuan yang telah ditetapkan.

Menurut Winardi perencanaan suatu tindakan yang meliputi tindakan memilih dan menghubungkan fakta-fakta dan mem-buat serta menggunakan asumsi mengenai masa yang akan datang dalam hal mem visualisasi serta merumuskan aktifitas-aktifitas yang diusulkan yang di-anggap perlu untuk mencapai hasil yang diingin-kan. ${ }^{16}$ Dengan demikian sebelum suatu organisasi melaksanakan aktivitasnya, pimpinan dari organisasi tersebut lebih dahulu harus merumuskan kegiatan-kegiatan yang dilaksanakan di masa datang dan hasil yang akan dicapai dari kegiatan-kegiatan tersebut, serta mekanisme pelaksanaannya. Dengan adanya rencana tersebut, maka aktifitas akan dapat terlaksana dengan baik.

Selain berfungsi sebagai perencanaan organisasi, anggaran merupakan salah satu cara untuk mengadakan pengawasan. Peng-awasan tersebut merupakan usaha yang ditempuh agar rencana yang telah disusun sebelumnya dapat dicapai. Dengan demikian pengawasan adalah mengevaluasi prestasi kerja dan tindakan perbaikan kinerja. ${ }^{17}$ Pengawasan tersebut dilakukan dengan membandingkan antara prestasi kerja dengan yang dianggarkan. Dari perbanding-an tersebut dapat ditemukan perilaku efisiensi, kinerja yang baik dalam mengelola organisasi. Tujuan pengawasan tersebut bukan untuk mencari kesalahan, akan tetapi untuk mencegah dan memperbaiki kesalahan serta untuk menjamin tercapainya tujuan-tujuan dan rencana organisasi.

Adapun fungsi koordinasi menuntut adanya keselarasan tindakan bekerja dari setiap individu atau bagian dalam orga-nisasi untuk mencapai tujuan. Dalam koor-dinasi tersebut diperlukan perencanaan yang baik, yang dapat menunjukkan keselarasan rencana antara satu bagian dengan bagian lainnya. Dalam konteks tersebut anggaran dapat dipakai sebagai alat koordinasi untuk seluruh bagian yang ada dalam organisasi, karena semua kegiatan yang saling berkaitan antara satu bagian dengan bagian lainnya sudah diatur dengan baik.

Fungsi anggaran yang lain adalah merupakan suatu rencana kerja yang disusun sistematis sehingga dapat menjadi pedoman kerja bagi setiap bagian dalam organisasi untuk menjalankan kegiatannya, karena penyusunan anggaran berdasarkan peng-alaman masa lalu dan prediksi pada masa yang akan datang.

Untuk mencapai tujuan organisasi fungsi anggaran tersebut perlu dimple-mentasikan. Dalam kerangka itulah, ang-garan harus disusun berdasarkan pada prinsip-prinsip anggaran yaitu, transparan, akuntabel, disiplin anggaran (efisien, tepat guna, tepat waktu dan dapat dipertanggung-jawabkan), keadilan (penggunaannya harus dialokasikan secara adil untuk kepentingan seluruh kelompok masyarakat), efisien dan efektif (harus dimanfaatkan sebaikbaiknya untuk meningkatkan pelayanan dan ke-sejahteraan bagi masyarakat).

16 Winardi, Azas-azas Manajemen, (Bandung: Penerbit Alumni,1983), h.149

17 Ibid 
Kalau dicermati prinsip-prinsip ang-garan tersebut sangat relevan dengan prinsip-prinsip hukum ekonomi Islam. Oleh karena itu penyusunan anggaran dengan penerapan prinsipprinsip hukum ekonomi Islam sudah menjadi keniscayaan. Adapun prinsip-prinsip hukum ekonomi Islam yang dapat diterapkan dalam penyusunan ang-garan, sebagai berikut:

1. Prinsip Tauhid (Unity/Ilahiyah/Ketuhanan) ${ }^{18}$ adalah prinsip umum dalam Islam, sehingga hukum ekonomi Islam pun menganut prinsip tersebut. Prinsip ini menegaskan bahwa semua manusia ada di bawah satu ketetapan yang sama, yaitu ketetapan tauhid yang dinyatakan dalam kalimat La'ilaha Illa Allah. Prinsip ini ditarik dari firman Allah QS. Ali Imran ayat 64. Berdasarkan atas prinsip tauhid tersebut, maka pelaksana-an hukum ekonomi Islam merupakan ibadah. Dengan demikian, bagi seorang muslim yang bekerja menyusun ang-garan, maka tidak lain karena sedang beribadah dan memenuhi perintah atau ketetapan Allah, sehingga anggaran yang disusun akan transparan, akun-tabel, disiplin dan dapat dipertanggung-jawabkan

2. Prinsip Keadilan (Equilibrium/ Keseim-bangan) ${ }^{19}$, adalah prinsip yang menuntut terwujudnya keseimbangan individu dan masyarakat, prinsip tersebut menghendaki jalan lurus dengan menciptakan tatanan sosial yang menghindari peri-laku merugikan. Dalam penyusunan anggaran harus dialokasikan secara adil untuk kepentingan seluruh kelompok masyarakat. Prinsip keadilan ini diambil dari QS. Al An'am ayat 152, QS. Al-Maidah : 8, QS. Al-Hujurat.

3. Prinsip Amar Makruf Nahi Munkar, adalah prinsip yang memposisikan ang-garan sebagai pedoman kerja, sehingga bagi yang melakukan penyimpangan (kemungkaran) dapat diberi sanksi, dan yang berprestasi diberi reward. Prinsip amar makruf nahi munkar tersebut ditegaskan dalam QS. Al-Imran : 104, 110, 114.

4. Prinsip Pertanggungjawaban (Responsi-bility), adalah prinsip yang menuntut komitmen mutlak terhadap upaya peningkatan kesejahteraan sesama manusia, sehingga penyusunan anggaran harus mempertanggungjawabkan ke-benarannya. Prinsip pertanggung-jawaban tersebut ditegaskan dalam QS. Al-Isra ayat 36 dan surat Al-Ahzab ayat 15.

\section{URGENSI FIQH ANGGARAN}

Umat Islam Indonesia semakin mem-perhatikan keputusan-keputusan atau kete-tapan ulamanya sendiri dan mempunyai kecenderungan untuk mengurangi keter-ikatan pada fiqh madzab fiqh yang empat, terutama terhadap ketetapan-ketetapan yang bersifat kontemporer. Kondisi tersebut ber-implikasi kepada tuntutan terhadap ulama dan cendekiawan muslim agar bersikap lebih responsif terhadap eskalasi persoalan ke-kinian disemua bidang, termasuk persoalan ekonomi seperti pengelolaan anggaran. Oleh karena itu, respon ulama dan cendekiawan muslim Indonesia akan adanya fiqh ang-garan, menjadi urgen untuk didiskusikan lebih lanjut, sebagai bentuk dinamika pemikiran hukum ekonomi Islam di Indonesia.

Mengkaji tentang fiqh anggaran, tidak bisa lepas dari kajian fiqh itu sendiri. Secara etimologis, fiqh diambil dari kata faqiha-yafqahu fiqhan yang berarti mengetahui dan memahami. Menurut Ibn Manzurfiqh berarti "mengetahui dan memahami

18 Syed Nawab Haider Naqvi, 1994, Islam Economics and Society, (London and New York: Kegan Paul International Ltd), h. Xviii.

19 Ibid., h. 71 
sesuatu". Sedangkan menurut terminologi ahli usul al-fiqh (usuliyyun), fiqh berarti ilmu tentang hukum-hukum syara' yang diperoleh mela-lui ijtihad.

Secara garis besar, unsur-unsur dalam definisi fiqh ini adalah: (1) ilmu tentang hukum syara'; (2) hukum Syara' tersebut berkaitan dengan perbuatan mukallaf yang bersifat praktis dan konkret $^{20}{ }^{2}$ (3) penge-tahuan itu diperoleh dengan cara ijtihad atau istidlal, yaitu mencurahkan segala potensi dan kesempatan dalam rangka mencapai kesimpulan hukum, (4) yang diderivatkan dari sumber pokoknya.

Sehingga ilmu ini hanya dapat diperoleh oleh orang yang sudah mencapai kualifikasi mujtahid. Dalam rangka kegiatan ini maka tidak dapat terlepas dari metodenya (ilmu usul alfiqh dan kaidah-kaidah fiqhiy-yah), sebagai acuan teoritis dan praktisnya. Oleh karena itu, fiqh disebut sebagai ilmu ijtihadi dan ahlinya (faqih) tidak lain adalah mujtahid itu sendiri. Terkait dengan definisi fiqh tersebut, maka fiqh anggaran dapat dikategorikan sebagai produk pemikiran fiqh yang harus mencakup empat unsur di atas, yaitu 1) berisi tentang hukum syara' (hukum Islam), dalam hal ini nilai-nilai dasar hukum Islam. Nilai-nilai dasar hukum Islam adalah nilai-nilai dasar Islam. Nilai-nilai dasar tersebut adalah kejujuran (sidq, amanah), keadilan, pertanggung-jawaban, kemanfaatan dan kesejahteraan; (2) hukum tersebut tentang perbuatan muka-llaf yang bersifat konkret dalam hal ini adalah pengelolaan anggaran; (3) hukum tersebut digali dengan menggunakan metode ijtihad dan istidlal; dan (4) hukum praktis tersebut digali dari sumber-sumbernya, yaitu Al-Qur'an, Sunnah, Ijma' dan logika ( $r a^{\prime} y$ ).

Namun, dalam rangka merumuskan fiqh anggaran tersebut tidak dapat terlepas dari seting sosial-budaya masyarakat dan pada zamannya, sehingga fiqh selalu mem-bawa warna lingkungannya. Hal ini mem-pertegas bahwa secara umum fiqh itu berpertegas bahwa secara umum fiqh itu bersifat zanni (relatif) ketika masih dalam tingkatan produk pemikiran, sehingga tidak mengikat setiap muslim. Fiqh bersifat dinamis (fleksibel), tidak bersifat universal dan dapat mengalami perubahan. Tetapi, ketika fiqh itu menjadi qanun atau hukum positif atau menjadi rujukan dalam kepu-tusan hakim dipengadilan maka otomatis mengikat setiap umat Islam atau para pihak. Adapun penerapan nilai-nilai dasar hukum Islam seperti shidq dan amanah ke dalam fiqh anggaran didasarkan kepada kaidah ushul fiqh yang menegaskan bahwa:

$$
\text { ما لا يتم الو جب اللا به فهو و اجب }
$$

Artinya "

sesuatu kewajiban tidak sempurna pelaksanaannya kecuali dengan adanya sesuatu hal, maka sesuatu hal tersebut hukumnya wajib pula". ${ }^{21}$

Dalam pengelolaan anggaran, kejuju-ran (shidq) tersebut adalah suatu kewajiban, yang tidak bisa dijalankan kecuali dengan penerapan prinsip trans-paransi anggaran. Oleh karena itu berdasarkan kaidah tersebut maka, melakukan transparansi anggaran adalah wajib. Perilaku jujur (shidq) (Q.S Maryam:41,56, Q.S at-Taubah : 119), sangat berkaitan dengan sifat amanah (Q.S. al-Qashash:26). Bila karakter amanah dipeli-hara, maka kejujuran (shidq) dapat ditegak-kan. Dalam hal ini shidq berkaitan dengan proses informasi anggaran,

20 Syamsul Anwar, Hukum Perjanjian Syari'ah, (Jakarta: PT. Raja Grafindo Persada, 2007), h. 8789.

21 H.A.Djazuli, Kaidah-kaidah Fikih: Kaidah-kaidah Hukum Islam Dalam Menyelesaikan Masalah-masalah Yang Praktis, (Jakarta: Kencana Prenada Media Group, 2006), h. 95-96. 
sedangkan amanah berkaitan dengan komitmen untuk mengalokasikan dan mendistribusikan ang-garan kepada yang berhak dalam rangka implementasi nilai-nilai kemanfaatan, kesejahteraan dan pertanggungjawaban. (QS al-Baqarah : 282, Q.S. al-Mujadalah : 7, Q.S al-Isra' : 34, 36, Q.S al-Furqan : 16, Q.S al-Ahzab: 15). Pengendalian shidq dan amanah dilakukan dengan membangun sistem pengawasan. Sistem kontrol atau pengawasan ini harus diimplementasi-kan dengan sangat tegas dan didukung oleh supremasi hukum yang mencerminkan nilai-nilai keadilan. (Q.S an-Nisa : 58 dan Q.S. al-Hujurat : 13)

Berdasarkan kepada kaidah ushul fiqh di atas, dapat ditegaskan bahwa pengawasan anggaran adalah suatu kewajiban karena, penerapan shidq dan amanah tidak ber-jalan, tanpa adanya pengawasan. Peng-awasan tidak dapat dilakukan dengan baik tanpa transparansi anggaran. Oleh karena itu dalam perspektif fiqh anggaran, menegak-kan transparansi (Q.S Ali Imran: 150 dan Q.Sasy-Syura: 38) anggaran adalah pelak-sanaan ibadah yang menempati kedudukan yang mulia dalam agama.

Dalam kerangka inilah penerapan nilai-nilai dasar hukum Islam dalam penyu-sunan anggaran menjadi sangat penting dalam upaya antisipasi kebocoran. Pada konteks ini eksistensi fiqh anggaran sangat urgen, karena bukan hanya demi kepen-tingan pribadi tetapi juga masyarakat. Oleh karena itu para pihak yang terlibat dalam penyusunan anggaran harus dikaitkan secara hukum, sehingga punya konsekuensi yang dapat dipertanggungjawabkan di muka pengadilan jika terjadi penyelewengan.

Pemaksaan hukum dalam bentuk fiqh anggaran ala Indonesia yang diangkat sebagai hukum positif seperti KHI dan KHES, memang masih terbuka lebar untuk didiskusikan. Tetapi sebagai antisipasi mani-pulasi dana, urgensi dari pemberian sanksi hukum bagi para pihak yang terbukti bekerja tidak jujur, menjadi sangat penting, ka-rena nilai-nilai Islam yang dikaitkan secara hukum tersebut, akan lebih mengikat dari-pada hanya dikaitkan secara moral atau etis yang tingkat ketaatannya sangat tergantung kepada kesadaran pribadi yang terkait. Karena sifat ketaatan yang bersifat subyektif tersebut secara proporsional keterikatannya relatif lemah.

\section{FIQH ANGGARAN SUATU UPAYA PENGENDALIAN}

Dalam Islam pengawasan yang ber-fungsi sebagai pengendalian dilakukan untuk meluruskan yang tidak lurus, mengo-reksi yang salah dan membenarkan yang hak. $^{22}$ Berdasarkan ruang lingkupnya, peng-awasan terbagi menjadi dua; pertama pengawasan internal (built-in control) yaitu, pengawasan yang berasal dari diri sendiri dan bersumber dari keimanan kepada Allah Swt (tauhid). Secara filosofis, fungsi pengawasan dalam Islam muncul dari pemahaman manusia akan tanggung jawab individu, amanah, dan keadilan. ${ }^{23}$

Pengawasan internal yang melekat dalam setiap pribadi muslim tersebut akan menjauhkannya dari bentuk penyimpangan dalam pengelolaan anggaran dan menuntun-nya konsisten menjalankan hukum-hukum Allah swt dalam setiap aktivitasnya. Yang kedua pengawasan eksternal (external control) yaitu, pengawasan eksternal yang dilakukan dari luar diri manusia dan terdiri atas mekanisme pengawasan dari pemimpin yang berkaitan dengan penyelesaian tugas yang telah didelegasikan, kesesuaian antara penyelesaian tugas dan perencanaan tugas terkait dengan anggaran dan lain-lain.

22 Abdul Mannan, Membangun Islam Kaffah, (Jakarta: Madina Pustaka, 2000), h. 152.

23 Ahmad Ibrahim Abu Sinn, Manajemen Syariah: Sebuah Kajian Historis Dan Kontemporer, (Jakarta: PT. Raja Grafindo Persada), h. 180 
Dari pengawasan internal tersebut, kemudian dibarengi dengan pengawasan eksternal dilakukan melalui mekanisme kepemimpinan yang adil, transparan, akun-tabel dan bertanggungjawab. Sebelum teknik pengawasan eksternal dapat dipergunakan atau disusun sistemnya, harus didasarkan kepada perencanaan yang jelas, lengkap dan terpadu untuk meningkatkan efektivitas pengawasan dalam organisasi. Hal tersebut dilakukan karena, pengawasan membutuh-kan struktur organisasi yang jelas, oleh karena itu harus diketahui oleh orang yang bertanggungjawab atas terjadinya penyim-pangan rencana sistem pengawasan dan yang harus mengambil tindakan untuk mem-benarkannya.

Dalam kerangka pengawasan ekster-nal tersebut, eksistensi fiqh anggaran layak diupayakan, sebagai suatu mekanisme pengendalian pimpinan dan staf dalam penyusunan anggaran suatu organisasi, yang disemangati prinsip pertanggungjawaban dan amar makruf nahi munkar. Adapun integrasi nilai-nilai dasar hukum Islam dalam perencanaan anggaran diwujudkan melalui tiga pilar pengawasan sebagai suatu pengendalian, yaitu; 1) ketaqwaan individu, 2) kontrol anggota, dan 3) supremasi hukum. ${ }^{24}$

Seluruh stakeholder organisasi harus dibina agar menjadi SDM yang bertaqwa disetiap tempat dan waktu agar mampu menjadi kontrol yang paling efektif. Selain itu perlu disusun mekanisme saling me-gawasi antar sesama anggota secara horizontal. Dengan demikian, dalam suasana organisasi yang mencerminkan formula tim, maka proses keberlangsungan organisasi selalu akan mendapatkan pengawalan dari para SDM-nya agar sesuai dengan arah yang telah ditetapkanbersama.

Ketaqwaan individu dan kontrol sesama anggota tersebut perlu dibarengi dengan penegakan hukum. Oleh karena itu, organisasi ditegakkan dengan aturan main yang jelas dan transparan. Sistem peng-awasan yang baik tidak dapat dilepaskan dari pemberian punishment (hukuman) dan reward (imbalan). Bentuk reward tidak harus materi tetapi dapat berupa penghargaan atau promosi jabatan. ${ }^{25}$

Dari paparan di atas dapat dipahami bahwa, upaya mewujudkan fiqh anggaran sebagai suatu sistem pengendalian dalam pengawasan anggaran tersebut, bukan hanya ajakan moral semata, tetapi dalam bentuk peraturan pengawasan anggaran dalam setiap perusahaan atau organisasi, baik mekanisme formal maupun mekanisme masyarakat, sehingga terdapat mekanisme reward (penghargaan) bagi yang berprestasi dan punishment (sanksi) bagi yang melaku-kan penyimpangan.

\section{PENUTUP}

Dalam pengelolaan anggaran, kejuju-ran (shidq) tersebut adalah suatu kewajiban, yang tidak bisa dijalankan kecuali dengan penerapan prinsip transparansi angga-ran. Oleh karena itu berdasarkan kaidah tersebut maka, melakukan transparansi anggaran adalah wajib. Dalam pandangan Islam, menghindari transparansi anggaran adalah suatu kemaksiatan. Penerapan nilai-nilai dasar hukum Islam dalam penyusunan anggaran menjadi sangat penting dalam upaya antisipasi kebocoran. Pada konteks ini eksistensi fiqh anggaran sangat penting, karena bukan hanya demi kepentingan pri-badi tetapi juga masyarakat. Oleh karena itu para pihak yang terlibat dalam penyusunan anggaran harus dikaitkan secara hukum, sehingga punya

24Anonim ,'Pengawasan Perspektif Islam" dikutip dari http://eei.fe.umy.ac.id . Akses pada tanggal 6 Feb 2015

25Didin Hafidhuddin, Manajemen Syariah Dalam Praktik, (Jakarta: Gema Insani Pers, 2003), h. 158 . 
konsekuensi yang dapat dipertanggungjawabkan didepan pengadilan jika terjadi penyelewengan.

\section{DAFTAR PUSTAKA}

Anthony dan Govindarajan. Management Control System, Penerbit Salemba Empat, Jakarta 2005.

Djazuli, H.A Kaidah-kaidah Fikih: Kaidah-kaidah Hukum Islam Dalam Menye-lesaikan Masalah-masalah Yang Praktis, Jakarta: Kencana Prenada Media Group, 2006.

Endang Raino Wirjono dan Agus Budi Raharjono, "Pengaruh Karakteristik Personalitas Manajer Terhadap Hubungan Antara Partisipasi Dalam Penyusunan Anggaran Dengan Kinerja Manajerial", Kinerja, Vol. 11 No. 1, thn 2007.

Glenn A.Welsch, Budgeting Profit Planning and Control, fourth edition, New Delhi: prentice hall of India Private Limited, 1981

Hafidhuddin, Didin. Manajemen Syariah Dalam Praktik, Jakarta: Gema Insani Pers, 2003.

Halim, Abdul Akuntansi Sektor Publik akuntansi Keuangan Daerah (Jakarta : Salemba empat, 2002

Hansen Don R, Momen, M, , Akuntansi Mangemen, Jakarta, Penerbit Salemba Empat: 2006

Ibrahim, Ahmad Abu Sinn, Manajemen Syariah: Sebuah Kajian Historis Dan Kontemporer, Jakarta: PT. Raja Grafindo Persada

Mannan, Abdul Membangun Islam Kaffah, Jakarta: Madina Pustaka, 2000

Mulyadi, Akuntansi Biaya (Yogyakarta: BP-STIE YKPN, 1993), h. 488

Schiff, M. and A.W. Lewin.. The Impact of People on Budgets.The Accounting Review. Vol. 45, 1970. pp. $259-268$

Syamsul Anwar, Hukum Perjanjian Syari'ah, Jakarta: PT. Raja Grafindo Persada, 2007

Syed Nawab Haider Naqvi, 1994, Islam Economics and Society, (London and New York: Kegan Paul International Ltd), hal. Xviii. Lihat juga Yusuf Qardhawi, Norma Dan Etika Ekonomi Islam, Jakarta: Gema Insani Press

Winardi, Azas-azas Manajemen, Bandung: Penerbit Alumni,1983 